\title{
ANALYTICAL OVERVIEW OF NEW APPROACHES TO THE STUDY OF HISTORICAL REALITY
}

\section{Dobrolyubska Yu. A.}

\section{INTRODUCTION}

Within the post-neoclassical subsystem of the philosophy of history, new approaches to the study of historical reality have emerged. Attention should be paid to analyzing the possibilities of applying synergistic concepts in the philosophy of history, as well as to attempts to construct theories of local civilizations in the context of globalization. Much attention is paid to the ideas and methods of synergetics, which offers a new perspective on the nature of the integrity of historical reality and allows one to study historical structures and processes in alternative situations of transition from chaos to order. Also, the post-neoclassical philosophy of history offers a synthetic concept of local civilizations in the context of their global interaction, which takes into account both the tendency for globalization and the tendency for localization. In the context of this understanding of civilization, it is recognized that in the modern world, on the one hand, there is a process of globalization, and on the other - the importance of civilizational differences. Universal idioms and meanings are perceived and understood by people through the civilizing prism of their historical experience, which contrasts with the "semiotic imperialism" of global culture.

\section{Limits of application of synergistic approaches}

Recently, the idea of methodological holism has been offered by synergetics, an area of scientific interdisciplinary research that deals with the study of cooperative phenomena in complex dynamic systems in the process of their self-organization ${ }^{1}$. The interest in the ideas of synergetics in historical science is due to the fact that it offers a new perspective on the nature of the integrity of historical reality. Using synergetics, researchers hope to overcome the methodological difficulties that arise when studying "steep turns of history" when alternative situations have arisen that imply a need for social choice. Synergetics provides an opportunity in the context of self-organization of society as a coherent system to re-examine such issues of historical development as possibility and reality, traditions and innovations, past and

${ }^{1}$ Качанов Ю.Л. Синергетика. Глобалистика: Энциклопедия. Москва: Радуга, Диалог, 2003. C. 919-920. 
present, alternative and choice $^{2}$. It emphasizes that human action is not something external to society as a self-developing system. Human action is included in the system, changing every time the field of its possible states ${ }^{3}$.

Some researchers, however, believe that the appeal to synergetics poses the danger of a positivist reduction of historical knowledge to natural science, since in this case the regularities of the processes of self-organization in the physical world are transferred to the development of society. They, in particular, express their doubts that within the framework of the synergistic approach one can generally consider "free will", since the synergetic itself lacks the necessary mathematical apparatus. In general, synergetics provides nothing more for historical analysis than the collection of new terms and metaphors. Therefore, in their opinion, the synergistic style of thinking does not contribute much to the reconstruction of the past, but rather turns the historical study into an experiment, which, due to the specifics of historical knowledge, is less productive than the traditional "hike" into the past ${ }^{4}$.

In this regard, it should be noted that although synergetics as a type of scientific rationality originated within the natural sciences in the 70's of the twentieth century, now it claims to be a new paradigm of scientific knowledge in general ${ }^{5}$. Therefore, the synergetic style of thinking that has emerged in search of a new holistic worldview, according to many domestic and foreign researchers, has a powerful methodological and heuristic potential. This is evidenced by the discussion that took place during the years 1991-1995 on the pages of the magazine "History and Theory". It involved both supporters and opponents of the use of synergetic ideas in historical research. Analyzing the materials of this discussion, it can be noted that the opponents of synergy were in the minority ${ }^{6}$. The synergetic style of thinking allows to develop non-standard approaches in the historical

2 Бородкин Л.И. "Порядок из хаоса": концепция синергетики в методологии исторических исследований. Новая и новейшая история. 2003. № 2. С. 98-118; Бородкин Л.И. Синергетика и история: моделирование исторических процессов. История и математика: Анализ и моделирование социально-исторических прочессов. 2007. С. 8-48.

${ }^{3}$ Степин В.С. Смена типов научной рациональности. Синергетика и психология. Bып. 1. Методологические вопросы. 1999. С. 113.

4 Бочаров А.В. Проблема альтернативности в истории: традиционные и нетрадиционные подходы. Историческое знание $u$ интеллектуальная культура: Материалы научной конференции. Москва, 4-6 декабря 2001 г. С. 29-33; Топольский Е. Дискуссия о применении теории хаоса к истории. Исторические записки. 1999. № 2 (120). С. 88-99.

5 Сапронов М.В. Концепция самоорганизации в обществознании: мода или необходимость? Общественные науки и современность. 2001. № 1. С. 150.

6 Бородкин Л.И. История и хаос: модели синергетики в дискуссиях историков. Историческое знание и интеллектуальная культура: Материалы научной конференции. Москва, 4-6 декабря 2001 г. С. 25. 
science, stimulating the solution primarily of those problems, which are caused by the interest in the search for unity in the variety of organic causes, ways and directions of historical evolution.

Synergetics as a theory of self-organization of complex systems is based on the ideas of the integrity of objective reality and the joint development of all levels of its material and spiritual organization, as well as scientific knowledge of the world. In this respect, synergetics, as a new worldview, is closely linked to the understanding of the world, traditional for oriental teachings and poetic creations, based on the conception of the unity of the world, the affinity of the living and the inanimate, the natural and the human, the universal and the microscopic ${ }^{7}$.

The synergistic worldview is based on the idea of an all-in-one, all-in-one communication. Such a worldview organically includes the view that small, insignificant, occasional details that make up a barely perceptible background can manifest their significance and lead to large, incomparable us.

Synergetics seeks to overcome the dismemberment of the world into living and inanimate nature. Considering nature as a creative system, synergetics in this sense brings its evolution closer to the history of society. Therefore, some of the ideas that are central to synergetics are genetically converging to those principled propositions that have long been the subject of reflection, for example, in historical knowledge. However, using advanced mathematical apparatus, synergetics rethinks these ideas, including them in the broader context of scientific ideas, creating universal models for explaining the processes occurring in complex systems, revealing the mechanism of selforganization of these systems, regardless of the nature of their elements.

Synergetics as a new paradigm of knowledge emerged as an opposition to positivism and classical rationalism. It blurs the line between nature and society, viewing them as phenotypes of one genotype - a complex system. In this sense, synergetics seeks to overcome the inferiority of the disciplinary dismemberment of a unified knowledge of the world and the processes of selforganization in it.

In scientific knowledge, synergetics acts primarily as a theory of selforganization of complex systems. These systems have the same nature of processes occurring at both macro and micro levels. The attribute of a complex system is emergence, that is, the irreducibility of the properties of the system as a whole to the properties of its components - subsystems and elements. Experts note that complex systems at a certain level of self-

7 Князева Е.Н. Случайность, которая творит мир (новые представления о самоорганизации в природе и обществе). В поисках нового мировидения: И. Пригожин, Е. и Н. Рерихи. Москва: Знание, 1991. С. 3-5. 
organization may have properties that do not boil down to the properties of its constituent elements. However, they emphasize that it is impossible to deduce by regular methods the properties of a complex system from the properties of its elements and features of their local development ${ }^{8}$.

In this regard, the synergistic style of thinking prohibits, for example, the historian from deriving the properties of society as a system from the properties of its economic, social or political subsystems, and the properties of supra-individual historical reality from the properties of individuals or the characteristics of their local interaction.

Complex systems are open, they lack rigid determination and process completeness. In this regard, the researcher who studies the past should represent it as a historical reality in the process of becoming and continuous emergence. Therefore, within the synergistic style of thinking, the categories of "historical being" and "historical development" are combined into a single conceptual framework.

Complex systems exist only on the basis of their inclusion in the outside world. Such systems, called "nested", maintain their existence by exchanging energy and information with other super- and subsystems. This also shows the openness of a difficult organized world.

The evolution of complex systems is a rhythmic process that underlies the transition from an unstable state of a system (chaos) to a relatively stable (order) and back. The rhythms of history have been drawn to attention for a long time, but synergetics makes it possible to interpret rhythmicity as a functional community of processes of self-organization of complex systems and to consider, for example, crisis and stability as natural-historical states of society, and "stagnation", "recession" or "recovery" in history does not not only as a consequence of someone's "miscalculations" or "wise" leadership, "but also as a manifestation of the mechanism of self-organization of social systems in the course of their evolutionary development.

Synergetics as a theory of self-organization of complex systems explains the mechanisms of origin, existence and destruction of ordered macrostructures that take place in such systems. According to this theory, the mechanisms of transition from chaos to order and back do not depend on the specific nature of the elements or subsystems. They are inherent in the world of natural (living and inanimate) and the world of human, social processes. Synergetics reveals common, universal mechanisms of self-organization. According to experts, it "makes clear the laws under which it is made, a unique picture of events in a wide variety of realms and scales of reality is written for scientists" .

${ }^{8}$ Моисеев Н.Н. Проблема возникновения системных свойств. Вопросы философии. 1992. № 11. С. 30-37.

${ }^{9}$ Князева Е.Н. Случайность, которая творит мир. С. 15. 
Complex systems are non-linear. In synergetics, nonlinearity is interpreted as a possibility of multivariate evolution of systems. Nonlinearity about history can be expanded by the idea of the irreversibility and alternative of the historical process and the possibility of social choice in a situation of historical uncertainty. The peculiarity of nonlinear systems is that with the same increments of external influences on the system, it can give different reactions depending on its initial state. Whereas the response of linear systems depends only on the magnitude of the increase of such influence. This feature of complex systems builds the effect of managing them: small external influences on the system can lead to significant consequences and, conversely, significant impacts can be negligible in the management plan. Knowledge of this effect gives the historian the opportunity to understand why, for example, many reforms did not lead to the desired outcome despite significant costs, and, conversely, small, seemingly eventful, sometimes catastrophic consequences.

In synergetics, there has been a rejection of the elemental particle (the bricks of objective reality) for the benefit of the world as a set of nonlinear processes characterized by alternative and irreversible development. In this regard, synergetics offers a qualitatively different picture of historical reality as compared to classical and non-classical science.

The basis of this picture is the idea of historical reality as a complex system, which in the process of self-organization goes through a historical cycle associated with the emergence of ordered macrostructures, their relatively stable existence and destruction. The emergence of stable macrostructures means the transition from chaos to order, the destruction of macrostructures - the transition from order to chaos ${ }^{10}$. Chaos is a characteristic of a complex system in a state of inequality and uncertainty. In terms of history, chaos is a "crisis", that is, a state of the social system in which its various subsystems, including the control unit and the public consciousness, cease to function properly. In a state of chaos in society, alternative situations arise, within which various possibilities for its further development emerge. The emergence of alternative situations gives a historical development probabilistic character, the detection of which involves the study of those historical possibilities that existed at a particular time in a particular historical situation.

Thus, synergetics, focusing on the problem of the probabilities of historical development, actualize the question of the relationship between the possible and the true in the historical process.

${ }^{10}$ Пригожин И., Стенгерс И. Порядок из хаоса. Новый диалог человека с природой. Москва: ЛКИ, 2008. 296 с. 
The past as historical reality as it came to be was invariant, that is unambiguous. The past as a historical reality has included various possibilities of historical development, and its invariance has been the result of the realization of one of these possibilities. It follows that an important task of historical research is to study not only invariants of historical development, but also those potential opportunities within which this invariant came about as a realization of one of them.

The emergence of different opportunities in the historical process is due to the ambiguity of the relationship between form and content, purpose and means of historical development. The same content of historical development can be expressed in different forms, but the same form of it can be filled with different content. Similarly, the same goal of historical action, depending on specific historical conditions, can be achieved by different means and, conversely, the same means may serve different purposes. All this, according to experts, leads to the emergence of different historical opportunities in the historical reality ${ }^{11}$.

In identifying and assessing real opportunities, it is important and complex, but it is necessary to define their temporal and spatial boundaries. In the course of historical development, every opportunity arises at a certain point in time. Given the right conditions created by social forces, it can turn into reality. But this may not happen if the effort is not enough. Some possibilities in general may remain potentialities not noticed by contemporaries. But in any case, the possibility has the limits of real existence. Ignoring these boundaries in the analysis of historical opportunities may lead the historian to make erroneous conclusions ${ }^{12}$.

Studying historical possibilities, researchers often regret that some of them were not noticed by contemporaries or misapplied, resulting in historical events not being as they might have happened. Historical scientific literature notes that the desire to see in the history of the implementation of any ethical and moral principles leads to "regret" about the so-called "missed opportunities" and "lost ways", "no reforms" and "no decisions" ". The historian may, of course, be guided by the motives of the "judgment on the past" and the drawing of "lessons of history," but the task of the researcher is first of all to find out and explain why and how certain historical possibilities were realized.

Since historical possibilities have a certain timeframe of their existence, their identification implies the study of specific alternative situations.

\footnotetext{
${ }^{11}$ Ковальченко И.Д. Методы исторического исследования. Москва: Наука, 1987. С. 76-77.

${ }^{12}$ Ковальченко И.Д. Методы исторического исследования. С. 71.

${ }^{13}$ Бочаров А.В. Проблема альтернативности в истории. С. 29.
} 
An alternative is a historical situation characterized by the existence of different historical opportunities, on the one hand, and by social forces, on the one hand, that are aware of these opportunities and capable of realizing them. Therefore, the occurrence of specific alternative situations in the historical reality was due to both objective and subjective factors.

Interest in the study of alternative situations in history has long existed and emerged in addition to synergetics, but it is within the framework of synergetics as a theory of self-organization of complex systems that a new interpretation of the mechanism for the realization of one or another historical possibility and its transformation into historical reality is provided. In historical science, the question of converting opportunity to reality has traditionally been associated with the presence of certain social forces that have actively sought to realize one or another historical opportunity. These forces, as noted in the historical literature, should realize this possibility, at least at the level of everyday knowledge of historical reality, align it with their interests and begin the struggle for its realization. At the same time, it was emphasized that the emergence of different opportunities is an objective process, the alternative is the subjective choice of existing opportunities and the struggle for the realization of the choice. Therefore, the subjective factor in the historical alternatives was the component that determined the result of the struggle for the realization of one or another development opportunity. This result depended on the balance of power, their commitment, cohesion and organization.

The cognitive interest of post-neoclassicism in alternative situations in historical reality is largely due to the fact that their study allows the historian, on the one hand, not to look constantly at current events, not to search for historical precedents, and to identify real historical opportunities ${ }^{14}$. On the other hand, the study of alternative situations allows post-neoclassics to realize the principle of holism in its subject area, which synthesizes the objective and subjective moments of historical development. And this is one of the methodological installations of the post-neoclassical subsystem of historical research.

Continuing the tradition of exploring alternative situations as the interrelations of objective and subjective, embedded in previous historiography, post-neoclassics, at the same time, believe that the cognitive capabilities of historical science in this field are greatly enhanced by synergetics.

${ }^{14}$ Тош Д. Стремление к истине: Как овладеть мастерством историка. Москва: Весь мир, 2000. С. 38 . 
Synergetics provide an opportunity to present the specific potentials of historical development and to re-discover the relationship and interrelation of what is necessary and accidental. According to this theory, at the point of bifurcation, when the transformation of possibilities into reality becomes a historical reality, the behavior of society as a complex system is characterized by instability and uncertainty and depends on some, relatively few, factors called order parameters. The order parameters that are formed in the higherlevel hierarchy system become control parameters for the lower-level subsystems. These parameters determine the behavior of subsystems of a complex system and seem to "subordinate" it to some single behavioral structure. The subsystems themselves, in turn, form the order parameters and thus a circular causal relationship occurs. Considering the time scales, the change of order parameters in the system is much slower than the changes of subsystems that "obey" it. The appearance of order parameters in a complex system is related to the interaction and competition of subsystems.

The order parameters should be distinguished from the control parameters, which are external actions that change the order parameters. Influences on control parameters in moments of bifurcation can lead to significant changes in the behavior of complex systems ${ }^{15}$. Thus, "order parameters" and "control parameters" play a crucial role in explaining self-organization processes at all levels of complex systems.

For historical study, it is of fundamental importance that society, as a complex system in an alternative situation, can dramatically change its condition under the influence of the smallest factors. Such factors are primarily the governing parameters or external influences on the system, which lead it to a certain attractor of historical development (relative sustainable existence of macrostructures) and turn one of the possibilities of development into historical reality.

According to synergetics, in the historical reality, as a nonlinear medium, at the point of bifurcation, there is potentially a spectrum of structures (forms of organization) that may appear in it. Moreover, what structures may arise in this environment, ie what are the possibilities of historical development, is determined solely by the internal properties of this environment, and not by the parameters of external influence. In other words, in the most historical reality, as a nonlinear medium, in the situation of alternativeness, the field of organically possible ways of its development is hidden. However, minor externalities (contingencies) can have a significant impact on the choice of this development.

\footnotetext{
${ }^{15}$ Качанов Ю.Л. Синергетика. С. 920.
} 
Synergetics also determine the prerequisite under which a small impact (chance) can lead to great results, to significant changes in the system. This condition is an unstable state of a nonlinear medium, which means that it is sensitive to small external influences generated by historical contingencies. It follows that the development of society as a complex system is, first, probabilistic and, second, irreversible. Probability is an attribute of the development of an open system, which plays an important role in evolutionary mechanisms, so from a synergistic point of view it is impossible to equate the probability of development with ignorance.

Considering history as an irreversible process, synergetics justify the inability to pose in the scientific consciousness such problems as "correcting the mistakes of the past" or "finding a way out of historical hopelessness". From the point of view of synergetics, "the mistakes of the past" cannot be corrected, as each new alternative situation creates its own spectrum of historical possibilities, the realization of which depends largely on chance. The same applies to "finding a way out of historical despair", since we cannot go back to the "fork of history" that supposedly led us off the true path of development. From the point of view of synergetics, the past at the point of bifurcation does not determine the present.

Thus, synergetics in studying the transition from chaos to order directs the researcher to search in the history of such situations that create real opportunities for the choice of ways and means of social development, their realization in the form of different options, as well as those factors that influenced this choice.

Synergetics as a theory of self-organization of complex systems also explains the transition from order to chaos associated with the destruction of the relatively stable state of ordered structures. For this purpose, the term "dissipation" is used in synergetics, which in the physical sense means the process of scattering the energy of an ordered state into the energy of an unregulated process. Dissipation is considered in synergetics not as an evil and a factor of destruction, but as an important property of self-organization, necessary for entering into "deterministic chaos". In this regard, the destruction of relatively stable social structures and the emergence of a "deterministic chaos" or crisis, accompanied by the development of an alternative situation, is a constructive beginning necessary for the further development of society as a complex system.

The transition from order to chaos is caused by changes in control parameters that have a devastating effect on the order parameters of a complex system. Synergetics play a significant role in these changes by fluctuations (random deviations). In history, the transition from chaos (the unstable state of the system of social relations) to the order 
(their relatively stable state) and back is a rhythmic process in which chance plays a constructive role.

Thus, an essential characteristic of a nonlinear world, complex systems, is randomness. Synergetics opens the special, creative role of chance in the processes of self-organization of complex systems. It forms a fundamentally important and unconventional view of chance, which plays in the nonlinear systems the role of the trigger mechanism, the force that can bring the system to the attractor (relative stable state), to one of its own structures of selforganization.

If, in classical science, randomness is merely an adjunct to the form of manifestation of necessity, a reflection of external, insignificant connections of reality, then synergetics assumes that, under certain conditions, necessity becomes an adjunct to chance. According to the ideas of synergetics, the unambiguous direction of the evolution of a nonlinear system after passing a bifurcation point is the result of correlation of mutually reinforcing fluctuations, so the need and chance in complex systems complement each other, in terms of rootedness in being equal.

Synergetics considers two types of fluctuations. The first kind is an accident that lies near the point of bifurcation (branching of possible ways of evolution of the system). Such a coincidence, which is at the origins of historical development, the emergence of a new one, determines the possible "wanderings" along the field of paths of this development and sets, in the end, its direction. In this case, historical necessity is born as a result of the play of chance. The second kind is a coincidence that complements the need and accompanies any process whose direction is already well defined. Here, chance burns out, cuts off all unnecessary things that prevent the system from entering the attractor - a relatively stable structure.

Thus, randomness in nonlinear processes plays a different role depending on the stage of self-organization of a complex system. Randomness near the point of bifurcation creates the need, and between the points of bifurcation is a coincidence of the second kind, ie constructive, due to its destructiveness.

Classical science, considering chance only as a complement to necessity, ignored chance as an insignificant factor in history, denying it, accordingly, the status of independent dimension of historical being. The new understanding of the role of chance in synergetics allows us to interpret the role of chance in history differently, considering it primarily as a constructive beginning of historical development and a cause for the emergence of a new one. The constructive role of chance in history is due to the fact that it triggers the mechanism of transition from one relatively stable situation to another, while choosing one of the paths of this transition, the possible spectrum of which is determined by the system itself. 
This is one of the most significant conclusions of synergetics. It radically changes the classical conceptions of the historical process, which, although they were oriented to the description of the individual and the accidental, because without that the very meaning of historical knowledge is lost, but in which only knowledge of historical necessity and historical regularities is recognized as scientific.

In classical historical science, coincidence was interpreted only as an occasion for historical events, which was never mixed with reasons (historical necessity). This is because, from the standpoint of classical science, necessity determines the unfolding of the historical process, and contingencies affect only its form. From a synergistic perspective, chance can be a factor that determines which of the objective possibilities will come true. Therefore, such a coincidence is no longer the cause of the unfolding of a chain of historical events, but the reason that the chain will unfold precisely in this and not in another sequence, although the spectrum of these possibilities is due to historical necessity.

Synergetics, which makes extensive use of mathematical apparatus to describe and explain processes, thus formalize the course of historical development, but at the same time "poetize" history. By restoring the role and significance of fluctuations (contingencies) in historical knowledge as an independent and important dimension of historical being, synergetics fills history with creative processes of evolution, considers the supra-individual historical reality as a creative system. The world is created by chance - this is one of the most important tenets of synergistic thinking. It is through chance that the historical world becomes beautiful in its random features.

Considering society as a complex system, synergetics at the same time does not identify the mechanisms of natural and social evolution. It views social reality as a creative world with incomplete information and changing values, a world in which the future can be represented in many ways. In so doing, the social problem of values can be broadly related to nonlinearity, because values are the spiritual codes of life used by people to keep the social system in some line of development that has been chosen by history. The value system therefore always resists the destabilizing effects of fluctuations generated by the system itself. This gives the historical process a whole trait of irreversibility and unpredictability.

Using the ideas of synergetics, scientific thinking demonstrates the benefits of a pluralistic interpretation of history and, at the same time, the limitations of monistic approaches. However, it warns professional historians of the admiration of the recognition of the synergetic status of universal scientific paradigm. 


\section{Synthetic concept of local civilizations}

At the turn of the XX - XXI centuries, the actualization of civilization discourse was conditioned by the theme of sociocultural pluralism of humanity, which returns from uniformity to specificity. Representatives of the post-neoclassical philosophy of historical research are distinguished by their desire to synthesize various metatheoretical constructs. This is clearly shown, for example, in attempts to address the problems of synthesis of formation and civilization theories in historical research.

Another attempt to synthesize different metatheoretical constructs is to construct a theory of local civilizations in the context of globalization. Today, it is no longer about the end of history as a victory for the civilizing ideas of the West. The subject of controversy was the civilizational concept of the formation of a new world order, proposed by S. Huntington. The focus has been on issues related to the content and prospects of civilizations in the modern world. The question of "the end of the history or struggle of civilizations" was transformed into a dilemma: "conflict or dialogue of civilizations" $"$.

However, the heuristic capabilities of existing civilization theories have proved insufficient to address these issues. There is a need to create new theories that, unlike their earlier variants, will be able to organically combine the study of the spiritually native and alien, general and special in history, the main trends of world development and local variants of the historical process, whose logic can only be understood within the framework of the worldview and value system of local cultures ${ }^{17}$.

Methodological reflection suggests that a new level of conceptualization is needed, which can set the paradigm of a new universalism. It is based on theories of "cultural pluralism" and those of globalization that posited a positive link between the process of globalization and the cultural diversity of the world. These theories define globalization as the formation of the integrity of the world in the form of a single space, including here and understanding of this process in different cultural discourses.

Within this paradigm, the "globalists", abandoning the Eurocentric vision of the world, went to meet the "localists", recognizing civilizations as the most important components of the global community and emphasizing that their theories of globalization posit a positive link between the process of globalization and the sociocultural diversity of the world. Contemporary

16 Тимофеев Т.Т. Противоречия глобализации и цивилизационные процессы. Глобализация. Конфликт или диалог ичивилизачий? Москва: Новый век, 2002. С. 10.

${ }^{17}$ Ионов И.Н. Теория циивилизаций от античности до концฺа ХІХ века. СПб.: Алетейя, 2002. C. 7-8. 
"localists", in turn, overcoming Spengler's thesis about the unity of humanity as a fallacious concept, no longer deny the existence of problems of global interaction. Therefore, they consider the interaction of local civilizations not only at the angle of their mutual socio-cultural correlation, but also in terms of their involvement in the problems and norms of the global, universal order. In this regard, experts emphasize that the imperative of theoretical analysis of civilizations in the modern world is to seek the principles of their interaction, conditioned and mediated by the world context ${ }^{18}$.

Post neoclassical philosophy of history comes up with the idea of overcoming the one-sidedness of globalist and mundialist approaches and offers a synthetic concept of local civilizations in terms of their global interaction, which takes into account both the tendency for globalization and the tendency for localization. Recognizing the existence of a global configuration of universal symbolic forms and even a global consciousness, post-neoclassics apply the concept of "civilization" only to those sociocultural entities that have the creative ability to produce (or process) universal symbols, that is, have the ability to communicate, understand and interpret. In doing so, they emphasize that individual civilizations produce their own evaluations of these universals (for example, freedom, human rights, power, etc.) and express them through the prisms of their values and historical experience. In this regard, some researchers generally regard local civilizations as "challenges" to global imperatives 19 .

Post neoclassics interpret civilization's functional desire for universality as a constant capacity for generalization and communication, and propose to base not the sociocultural code, but the principle of "correlation" of its symbolic universals, on the definition of local civilization.

In the context of this understanding of civilization, it is recognized that in the modern world, on the one hand, there is a process of globalization, and on the other - the importance of civilizational differences. Universal idioms and meanings are perceived and understood by people through the civilizing prism of their historical experience, which contrasts with the "semiotic imperialism" of global culture. Therefore, various local civilizations retain their vitality, as they serve as a basis for self-expression of the masses of the population, for the production of appropriate symbols.

Thus, within this version of the civilizational approach, on the one hand, the modern world is seen as the gravitas of civilizations and the civilization of the meeting, on the other, the civilizations themselves become possible only

18 Чешков М.А. Осмысление мироцелостности: новая оппозиция идей или их сближение? Мировая экономика и международные отношения. 1995. № 2. С. 148.

19 Чешков М.А. Осмысление мироцелостности. С. 151. 
as a "meeting of civilizations" as their dialogue on the basis of common symbolic forms. On this basis, there is a specific civilization interpretation of universal universals and their global configuration is made.

Such an interpretation of civilizations overcomes the idea of them as discrete sociocultural units. Innovation in such an interpretation of the concept of "civilization" is that both civilizational and mondialist approaches are implemented, the socio-cultural specificity of civilizations is recognized, and an ecumenical vision of the world is preserved, the interconnection of localism and globalism is established through the mediation of the universal-symbolism.

The complexity of the creation of new civilization theories is that in modern scientific discourse there is a wide variation of meanings and meanings in which the concept of "civilization" is used. This provides the basis for some scholars to argue that the single, universally recognized meaning of the term "civilization" does not exist, in different contexts the term may mean directly opposite concepts. Therefore, the term "civilization", as noted by modern researchers, became the embodiment of "blooming roar of disorder", in which there are dozens of civilizations on one continent, then appears a single world civilization" 20 .

It should be noted that the concept of "civilization" refers to the semantically very capacious, and in the modern world it is used so often that sometimes they simply forget about definitions. At the same time, there is complete arbitrariness among modern ideas about civilizations, and science has no methodological tools at all to isolate the system-forming grounds of civilization. Some researchers generally doubt the feasibility of using this concept in research practice.

The philosophical and historical scientific literature emphasizes that the diversity of interpretations of the concept of civilization does not allow to unambiguously define some specific social reality that could once and for all be included in the heading of "civilizations". Researchers are not able to single out the deep internal basis that makes all civilizations something unified, allowing to integrate in a single logical space the ethnic, economic, social and cultural characteristics taken in their world-historical distribution. Therefore, the concept of civilization to a greater extent serves not as a reflection of some social reality, but as a philosophical principle with a very vague content, as a rather blurred general sociological setting, which allows to "divide" society into certain "sections" 21 .

${ }^{20}$ Ерасов Б.С. Введение. Цивилизация: слово-термин-теорія. Сравнительное изучение иивилизаиий. Москва: Аспект Пресс, 1998. С. 9-35.

${ }^{21}$ Найдыш В. М. Проблема цивилизации в научной мысли нового времени. Человек. 1998. № 2. C. 20. 
This suggests that the concepts of civilization used in contemporary literature are only mental constructs created independently of empirical reality. This was first pointed out by R. J. Collingwood, who believed that "civilization" refers to those concepts that are called philosophical, metaphysical, or transcendent, arising through the reflective capacity of judgment, independent of empirical material.

The actualization of the problem of "interaction of civilizations in the conditions of globalization" implies clarification of the heuristic possibilities, first of all different local historical concepts of civilization. There are two such concepts - one-dimensional and multidimensional. Within the framework of a one-dimensional concept, a narrow (one-factor) and broad (multi-factor) interpretation of the concept of civilization was formed. In the context of a narrow interpretation of the concept of local civilization, taking into account the dominant factor, there are several approaches in its interpretation: cultural, ethno-psychological, environmental and sociological. In general, a cultural approach prevails, in which local civilization is either identified with culture or culture is considered as the basis of civilization ${ }^{22}$. In line with the cultural approach from Weber is a tradition within which the foundations of local civilizations are seen in religion. V. M. Mezhuev holds a similar position, who believes that with some controversy, "the definition of a civilization that identifies it with culture (which is generally characteristic of the Anglo-American scientific tradition), it correctly captures the initial difference of one civilization from another - a type of religious belief, that is, the culture in that part in which it has not yet separated from the cult". In this sense, "religion is as if the last frontier between civilizations"23.

The ethnopsychological approach is based on the premise: how many peoples - so many civilizations. He began the ethnographic concept of the civilizations of T. Juffroy, who expressed in the 30-ies of the XIX century the idea that each nation has its own civilization. Therefore, within this approach, the concept of civilization connects, on the one hand, with the peculiarities of ethnic history, and on the other - with the psychology (national character) of a particular people ${ }^{24}$.

In modern literature, there are ideas about local civilizations based on both ethnopsychological and cultural approaches. In this case, the concept of civilization boils down to the "identity of the culture and psychology of each

22 Хантингтон С. Столкновение цивилизаций и переустройство мирового порядка. Pro et Contra. 1997. T. 2. № 2. C. 117.

${ }^{23}$ Межуев В. М. Философия истории и историческая наука. Вопросы философии. 1994. № 4. C. 75 .

24 Добролюбська Ю.А. Тип мислення та рівень культури: проблема співвідношення. Культура народов Причерноморья. № 35. 2002. С. 125-127. 
nation" while maintaining their interdependence and intrinsic integrity at all stages of history. Thanks to what in a certain historical, cultural and geographical space for millennia there is a reproduction of various factors of spiritual and material culture, traditions and customs of peoples.

Within the framework of the ecological approach, the idea has emerged that the decisive influence on the character of civilization is exerted by the geographical environment of the existence of a particular people, which influences first and foremost the forms of cooperation of people, which gradually change nature. This approach involves considering local civilizations in the context of the unity of society and its place of existence. In this case, civilization is understood as stable in its main typological features of the historical-cultural and socio-economic system, determined by the peculiarities of natural landscape conditions, which is reflected in a specific complex of economic, social, spiritual and psychological features.

In the context of a broad (multifactorial) interpretation of the concept of local civilization, a synthetic approach has emerged, whose representatives believe that the basis of local civilization is not one factor, but the interaction of various factors. The foundations of a broad interpretation of the concept of civilization were laid by French scientists. Thus, in A. Nichiforo civilization is a set of ways of being and activity of a group of people, expressed in material, intellectual and moral life, political and social organization.

Broad interpretation of the concept of civilization adhered to and representatives of the school "Annals", in which it essentially became a synonym for society. This allowed the term "civilization" to be applied to any complex societies in which both economic factors and the social system are important, as are the moral principles of regulation of relations, and the political system, both practical knowledge and aesthetic ideals.

In the Soviet scientific tradition, in the context of a broad interpretation of the concept of civilization, the idea of a whole self-evolving social system, includes all social and non-social components of the historical process, the entire set of human material and spiritual objects. The foundations of this understanding of civilization were laid by M. A. Barg, who characterized civilization as conditioned by natural conditions of life, on the one hand, and objectively its historical preconditions - on the other, the level of development of human subjectivism, manifested in the way of life of individuals, in the way they communicate with nature and the like ${ }^{25}$.

The use of one-dimensional narrow and broad interpretations of the concept of "civilization" in research practice raises a number of

25 Барг М.А. Категория “цивилизация” как метод сравнительно-исторических исследований. История СССР. 1991. № 5. С. 68-77. 
methodological difficulties, since they are not universal, and therefore, undoubtedly, having some heuristic potential in the study of some civilizations, reveal the methodological inefficiency of others. The broad, or synthetic, approach does not contain any clear criteria for isolating a local civilization, identifying essentially the concepts of society and civilization.

Analysis of existing approaches to the construction of the concept of local civilization allows us to draw a fairly significant conclusion. Attempts to derive from the empirical material the universal meaning of the concept of civilization have not been successful. Moreover, the very concept of "civilization" is often summed up by various phenomena of reality. This suggests that the term "civilization" is a "framework concept", that is, within the same conceptual content is allowed to impose it on different areas, societies and stages. In general, it can be stated that the concepts of local civilization, represented in contemporary discourse, are largely intellectual projects - ideas embodied in "constructive reality".

\section{CONCLUSIONS}

The idea of local civilization as an idea and transcendental concept requires appropriate methodological reflection, which leads to think first of all those forming the basis of civilization, which will turn the idea of civilization into an instrument of cognitive activity. This implies the creation of such a universal methodological construct for the study of unique civilizations, the heuristic potential of which can be used in solving specific research problems, including comparative ones. Universal not in the sense that it claims to be one, but in the sense that it can be used to identify the specifics of local civilizations in the course of their comparative study on the basis of some common parameters for them.

One such construct can be created in the context of the post-neoclassical system of historical scientific inquiry.

The advantages of such a multidimensional approach are that it can describe various multicultural civilizations, characterized by the intense interplay of many unique cultures and world religions, to determine the potential field of possible interactions of civilizations in the context of globalization, as well as civilizational responses to its challenges.

\section{SUMMARY}

The ideas and methods of synergetics are analyzed, which offers a new perspective on the nature of the integrity of historical reality and allows to study historical structures and processes in alternative situations of transition from chaos to order. Synergetics provides an opportunity, in the context of self-organization of society, as a coherent system, to re-examine such issues 
of historical development as possibility and reality, traditions and innovations, past and present, alternative and choice. According to synergetics, in the historical reality, as a nonlinear medium, at the point of bifurcation, there is potentially a spectrum of structures (forms of organization) that may appear in it. Moreover, what structures may arise in this environment, ie what are the possibilities of historical development, is determined solely by the internal properties of this environment, and not by the parameters of external influence. In the most historical reality, the field of organically possible ways of its development is hidden as a nonlinear environment in the situation of alternativeness. However, minor externalities (contingencies) can have a significant impact on the choice of this development.

Synergetics also determine the prerequisite under which a small impact (chance) can lead to great results, to significant changes in the system. This condition is an unstable state of a nonlinear medium, which means that it is sensitive to small external influences generated by historical contingencies. It follows that the development of society as a complex system is, first, probabilistic and, second, irreversible. Probability is an attribute of the development of an open system, which plays an important role in evolutionary mechanisms, so from a synergistic point of view it is impossible to equate the probability of development with ignorance. Synergetics in the study of the transition from chaos to order directs the researcher to search in the history of such situations, which create real opportunities for the choice of ways and means of social development, their realization in the form of different options, as well as those factors that influenced this choice.

Another attempt to synthesize different metatheoretical constructs - the theory of local civilizations in the context of globalization - is also explored. Post neoclassical philosophy of history comes up with the idea of overcoming the one-sidedness of globalist and mundialist approaches and offers a synthetic concept of local civilizations in terms of their global interaction, which takes into account both the tendency for globalization and the tendency for localization. Recognizing the existence of a global configuration of universal symbolic forms and even a global consciousness, post-neoclassics apply the concept of "civilization" only to those socio-cultural entities that have the creative ability to produce (or process) universal symbols, that is, have the ability to communicate, understand and interpret. In doing so, they emphasize that individual civilizations produce their own evaluations of these universals (for example, freedom, human rights, power, etc.) and express them through the prisms of their values and historical experience. In this regard, some researchers generally regard local civilizations as "challenges" to global imperatives.

Post neoclassics interpret civilization's functional desire for universality as a constant capacity for generalization and communication, and propose to 
base not the sociocultural code, but the principle of "correlation" of its symbolic universals, on the definition of local civilization. In the context of this understanding of civilization, it is recognized that in the modern world, on the one hand, there is a process of globalization, and on the other - the importance of civilizational differences. Universal idioms and meanings are perceived and understood by people through the civilizing prism of their historical experience, which contrasts with the "semiotic imperialism" of global culture. Therefore, various local civilizations retain their vitality, as they serve as a basis for self-expression of the masses of the population, for the production of appropriate symbols.

\section{REFERENCES}

1. Качанов Ю.Л. Синергетика. Глобалистика: Энциклопедия. Москва: Радуга, Диалог, 2003. С. 919-920.

2. Бородкин Л.И. "Порядок из хаоса": концепция синергетики в методологии исторических исследований. Новая и новейшая история. 2003. № 2. С. $98-118$.

3. Бородкин Л.И. Синергетика и история: моделирование исторических процессов. История и математика: Анализ $и$ моделирование соииально-исторических процессов. 2007. С. 8-48.

4. Степин В.С. Смена типов научной рациональности. Синергетика и психология. Bып. 1. Методологические вопросы. 1999. С. 112-132.

5. Бочаров А.В. Проблема альтернативности в истории: традиционные и нетрадиционные подходы. Историческое знание $u$ интеллектуальная культура: Материалы научной конференции. Москва, 4-6 декабря 2001 г. С. 29-33.

6. Топольский Е. Дискуссия о применении теории хаоса к истории. Исторические записки. 1999. № 2 (120). С. 88-99.

7. Сапронов М.В. Концепция самоорганизации в обществознании: мода или необходимость? Общественные науки и современность. 2001. № 1. С. 148-161.

8. Бородкин Л.И. История и хаос: модели синергетики в дискуссиях историков. Историческое знание и интеллектуальная культура: Материалы научной конференции. Москва, 4-6 декабря 2001 г. C. 24-28.

9. Князева Е.Н. Случайность, которая творит мир (новые представления о самоорганизации в природе и обществе). B поисках нового мировидения: И. Пригожин, Е. и Н. Рерихи. Москва: Знание, 1991. C. 3-31.

10. Моисеев Н.Н. Проблема возникновения системных свойств. Вопросы философии. 1992. № 11. С. 30-37. 
11.Пригожин И., Стенгерс И. Порядок из хаоса. Новый диалог человека с природой. Москва: ЛКИ, 2008. 296 с.

12. Ковальченко И. Д. Методы исторического исследования. Москва: Наука, 1987. 440 с.

13. Тош Д. Стремление $\kappa$ истине: Как овладеть мастерством историка. Москва: Весь мир, 2000. 294 с.

14. Тимофеев Т.Т. Противоречия глобализации и цивилизационные процессы. Глобализация. Конфликт или диалог цииилизаций? Москва: Новый век, 2002. С. 6-12.

15.Ионов И.Н. Теория цивилизаџий от античности до конияа ХІХ века. СПб.: Алетейя, 2002. 384 с.

16. Чешков М.А. Осмысление мироцелостности: новая оппозиция идей или их сближение? Мировая экономика и международные отнотения. 1995. № 2. С. 146-153.

17. Ерасов Б.С. Введение. Цивилизация: слово-термин-теорія. Сравнительное изучение иивилизаиий. Москва: Аспект Пресс, 1998. C. 9-35.

18. Найдыш В.М. Проблема цивилизации в научной мысли нового времени. Человек. 1998. № 2. С. 6-23.

19. Хантингтон С. Столкновение цивилизаций и переустройство мирового порядка. Pro et Contra. 1997. Т. 2. № 2. С. 114-154.

20. Межуев В.М. Философия истории и историческая наука. Bonpocbl философии. 1994. № 4. С. 74-86.

21. Добролюбська Ю.А. Тип мислення та рівень культури: проблема співвідношення. К Культура народов Причерноморья. № 35.2002. C. $125-129$.

22. Барг М.А. Категория “цивилизация" как метод сравнительноисторических исследований. История СССР. 1991. № 5. С. 68-77.

\section{Information about the author:}

Dobrolyubska Yu. A.,

Doctor of Sciences in Philosophy, Professor, Head of the Department of World History and Methodology of Science, South Ukrainian National Pedagogical University named after K. D. Ushinsky 26, Staroportofrankivska str., Odesa, 65020, Ukraine 